\title{
Exposure of gasoline professionals to leaded gasoline in Asyut governorate
}

\author{
Hatem Abdel Moniem Ahmed ${ }^{1}$, Shaaban M. Ahmed ${ }^{2}$ \\ ${ }^{1}$ Department of Forensic Chemistry, College of Forensic Sciences, Naïf Arab University for Security Sciences, Riyadh, Saudi Arabia \\ ${ }^{2}$ Asyut Lab. of Medico-legal Department, Ministry of Justice, Asyut Branch, Egypt \\ *Corresponding author E-mail: Hatemahmed29@nauss.edu.com
}

Copyright () 2015 Hatem Abdel Moniem Ahmed, Shaaban M. Ahmed. This is an open access article distributed under the Creative Commons Attribution License, which permits unrestricted use, distribution, and reproduction in any medium, provided the original work is properly cited.

\begin{abstract}
Background: Gasoline is a complex manufactured mixture that does not exist naturally in the environment and produced from petroleum in the refining process. Gasoline discussed in this profile is automotive gasoline used as a fuel for engines in automobiles and other vehicles. Unleaded gasoline was introduced in the greater area Asyut, and 10\% of the total sales of gasoline were unleaded. There were no previous studies on pollution caused by gasoline exposure in Asyut governorate in Upper Egypt, so, in this study we try to concern on the effect of air pollution from automobile exhaust on hematological and biochemical parameters of professionals.

Materials and methods: Hundred and twenty samples from professionals have been collected from Asyut Governorate; they divided into four groups each group contain thirty samples. 10 milliliter of venous blood sample was withdrawn, over EDTA, from each individual, to determine the values of hematological, biochemical parameters and blood-lead level.

Results and discussion: According to the present study, it was found that there was a significant increase in blood-lead level, hemoglobin levels and white blood cells count in all of the exposed groups. On the other hand, creatinine level shows significant decrease but there were a significant increase urea level and increase in some liver function's levels (ALT and AST) in all tested groups.

Conclusion: The exposure to gasoline caused some toxic lesions on some parameters (hematological and biochemical). It is also observed that enzyme activity (AST, ALT) increase significantly compared with control.

Keywords: Gasoline; Asyut Governorate; Gas-Station Employees; Taxi Drivers; Bus Drivers.
\end{abstract}

\section{Introduction}

Asyut Governorate is one of the governorates of Egypt. It stretches for about $120 \mathrm{~km}$ along the banks of the Nile. There is considerable evidence linking increased levels of air pollution to adverse effects on human health [1,2]. Egypt is littered with garbage, pollution and people who do not care about their country. The use of gasoline as motor fuel was addressed here; automotive gasoline is a mixture of about 150 chemicals refined from crude oil relatively volatile hydro carbons with or without additives obtained by blending appropriate refinery streams; it's usually a colorless, light brown or pink liquid [3]. Lead is the main component of gasoline; typically, lead enters the human body through the respiratory or gastrointestinal tract and is distributed in blood, soft tissues, and bones [4]. Many of the harmful effects seen after exposure to gasoline are due to the individual chemicals in the gasoline mixture, such as benzene and lead in very small amounts. It has been suggested that emission of increased numbers of ultrafine $(<0.1$ micron $)$ particles of organic condensate may accompany the reduction of elemental carbon particles [5]. Changes in gasoline and diesel fuels and spark- and compression-ignition engine control technologies have clearly reduced the total particulate mass emissions, but changes in chemical composition are less certain [6]. Lead pollution from engine exhaust is dispersed into the air and into the vicinity of roads and easily inhaled. Contact with concentrated tetraethyl lead (TEL) leads to acute lead poisoning: Lead is a toxic metal that accumulates in the body and is associated with subtle an 
insidious neurotoxic effects especially at low exposure levels, such as low IQ and antisocial behavior [7]. Some neurologists have speculated that the lead phase-out may have caused average IQ levels to rise by several points in the US (by reducing cumulative brain damage throughout the population, especially in the young). For the entire US population, during and after the TEL phase out, the mean blood lead level dropped from16 $\mu \mathrm{g} / \mathrm{dl}$ in 1976 to only $3 \mu \mathrm{g} / \mathrm{dl}$ in 1991. The US Centers for Disease Control considered blood lead levels "elevated" when they were above10 $\mu \mathrm{g} / \mathrm{dl}$. Lead exposure affects the intelligence quotient (IQ) such that a blood lead level of $30 \mu \mathrm{g} / \mathrm{dl}$ is associated with a 6.9-point reduction of IQ, with most reduction (3.9 points) occurring below $10 \mu \mathrm{g} / \mathrm{dl}$ [8]. Reduction in the average blood lead level is believed to have been a major cause for falling violent crime rates in the United States [9] and South Africa [10]. Economist Jessica Wolpaw Reyes of Amherst College found that declining exposure to lead is responsible for up to a 56\% decline in crime from 1992 to 2002. Including other factors that are believed to have increased crime rates over that period Reyes found that this led to an actual decline of $34 \%$ over that period [11]. A statistically significant correlation has been found between the usage rate of leaded gasoline and violent crime: taking into account a 22-year time lag, the violent crime curve virtually tracks the lead exposure curve. Major symptoms of intoxication with leaded gasoline include headache, fatigue, irritability, impaired concentration, wrist/foot drop, nausea, dyspepsia, constipation, colic, lead line on gingival tissue, loss of libido and anemia [12]. The aim of this work is study the blood lead level exposure and the gasoline exposure effect on blood-lead hematological and biochemical parameters of taxi, Bus drivers and gas station employees.

\section{Materials and methods}

This study was done through the period from September to end of November, 2014, at department of forensic chemistry, college of forensic sciences, naïf Arab university for security sciences, Riyadh, Saudi Arabia, the samples collected from July to end of August, 2014. Hundred and twenty samples have been collected from Asyut Governorate. They divided into four groups each group contain thirty samples; bus drivers (group A), gas station employees (group B) and taxi drivers (group C), all of them worked in the center and near suburbs of the city of Asyut city and control (D group). The subject population age (19-45) years comprised. The information about past and present medical histories for each subject are collected, including smoking habits and overall duration of lead exposure and cancelled the smokers or patients from research. 10 milliliter of venous blood sample were withdrawn, over EDTA, from each individual by qualified personnel under aseptic conditions to determine values of hematological level, including (hemoglobin ( $\mathrm{Hb}$ ), white blood cells count), according to Bernard [13], and for measuring quantitative analysis of blood-lead level according to Simeonove [14], with the atomic absorption spectrometry device (240FS AA, from Agilent Technologies, with (Graphite Furnace) GTA 120 , PSD 120 (Programmable) [15]. Biochemical parameters, the activities' serum aspartate aminotransferase (AST) and alanine aminotransferase (ALT) were assayed by the method of Reitman [16], where creatinine and urea in serum were assessed as a measure of kidney function according to Bartels [17]. Statistical Analysis: The obtained data were statistically analyzed using F. Test - ANOVA test according to (Snedecor and Cochran) [18].

\section{Results}

Table. 1: Mean Values of Blood-Lead Level in Control and Test Professional's.

\begin{tabular}{|c|c|c|c|c|}
\hline Parameter & $\begin{array}{l}\text { Bus drivers } \\
\text { (Group A) }\end{array}$ & $\begin{array}{c}\text { Gas station Employees } \\
\text { (Group B) }\end{array}$ & $\begin{array}{c}\text { Taxi drivers } \\
\text { (Group C) }\end{array}$ & $\begin{array}{c}\text { Control } \\
\text { (Group D) }\end{array}$ \\
\hline $\begin{array}{l}\text { Blood Lead } \\
\text { Level }(\mu \mathrm{g} / \mathrm{dl})\end{array}$ & $7.1 \pm 0.6519 . *$ & $7.16 \pm 0.5413 . *$ & $7.14 \pm 0.3435 . *$ & $5.56 \pm 0.498 *$ \\
\hline
\end{tabular}

Lead Level

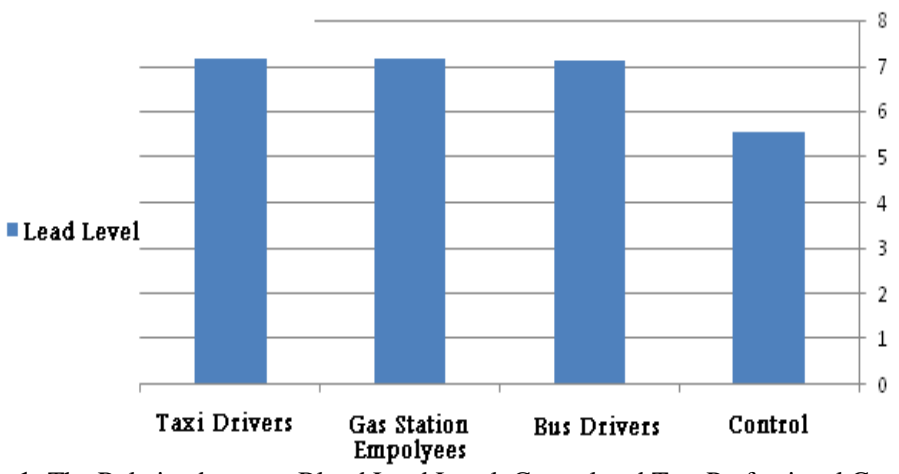

Fig. 1: The Relation between Blood Lead Level, Control and Test Professional Groups 
Table. 1. The relation between blood lead level, control and test professional groups. The results showed significant ( $\mathrm{p}$ $<0.05$ ) increase in blood lead level between control and test groups (fig. 1).

Table. 2: Mean Age (in Years) with Changes of Blood Lead Level in Professional Grops

\begin{tabular}{cccc}
\hline Age & $\begin{array}{c}\text { Bus driver } \\
(\text { Group A) }\end{array}$ & $\begin{array}{c}\text { Gas station employees } \\
\text { (Group B) }\end{array}$ & $\begin{array}{c}\text { Taxi drivers } \\
(\text { Group C) }\end{array}$ \\
\hline $19-23$ & 7.5 & 7.1 & 7.2 \\
$24-26$ & 6.8 & 6.8 & 7.6 \\
$27-31$ & 7.9 & 7.8 & 7.0 \\
$32-38$ & 7.1 & 6.5 & 6.8 \\
$39-45$ & 6.2 & 7.6 & --- \\
\hline
\end{tabular}

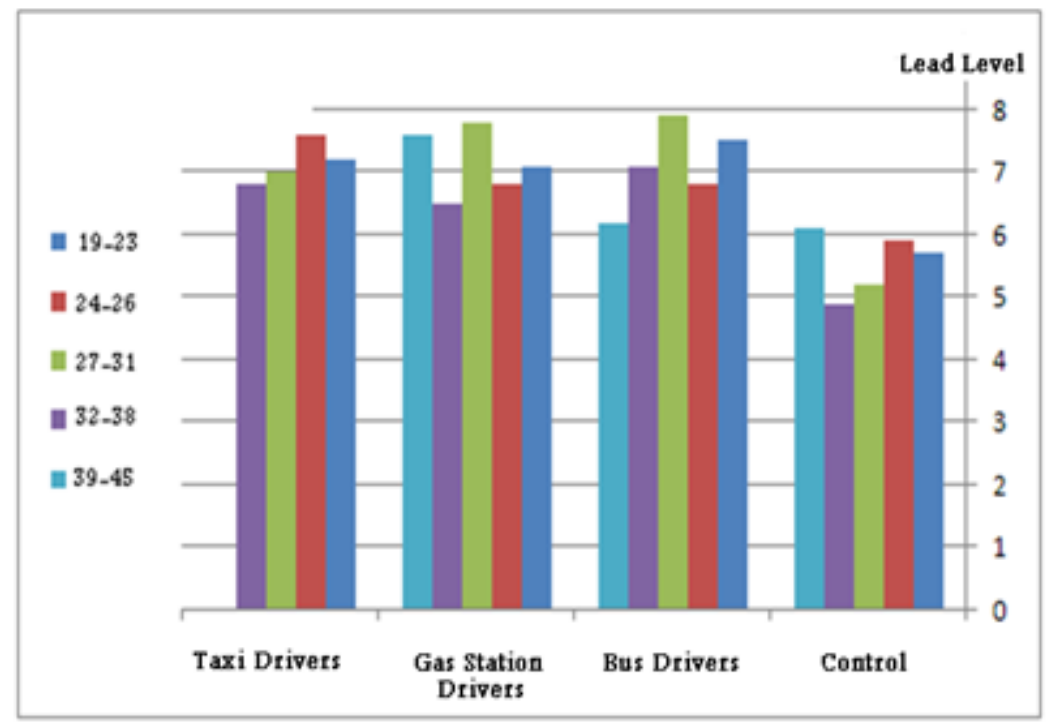

Fig. 2: Mean Age (in Years) with Changes of Blood Lead Level in Professional Grops

Table. 2. The mean values of lead levels of test professionals and control groups with age, wher the age peroids were between 19-45 in the test and control groups (Table. 2) (Fig. 2). The results showed that, there is an increas of lead level with icreasing of age. Further suggests that prolonged exposure to gasoline is related to age in all groups.

\subsection{Effect of lead level on hematological parameters}

Table. 3: Mean Values of Hematological Parameters in Control and Test Professional.

\begin{tabular}{lcccc}
\multicolumn{5}{c}{ Table. 3: Mean Values of Hematological Parameters in Control and Test Professional. } \\
\hline Test groups & $\begin{array}{c}\text { Bus drivers } \\
\text { (Group A) }\end{array}$ & $\begin{array}{c}\text { Gas Station Employees } \\
\text { (Group B) }\end{array}$ & $\begin{array}{c}\text { Taxi drivers } \\
\text { (Group C) }\end{array}$ & $\begin{array}{c}\text { Control } \\
(\text { Group D) }\end{array}$ \\
\hline Hemoglobin $(\mathrm{g} / \mathrm{dl})$ & $6.16 \pm 0.6205 *$ & $6.26 \pm 0.6269 *$ & $7.2 .26 \pm 0.7059 *$ & $14.3 \pm 0.1938 *$ \\
WBC $(\times\{10 . \sup .3\}$ & $7.44 \pm 0.4159$ & $6.62 \pm 0.455$ & $7.1 \pm 0.3674$ & $8.92 \pm 0.5864$ \\
$/\{$ mm.sup.3\}) & & & & \\
\hline
\end{tabular}

* Significant $(\mathrm{P}<0.05)$ decrease within the groups (normal and test values t-test)

* Not Significant $(\mathrm{P}>0.05)$ between groups (ANOVA)

Table. 3. The mean values of hematological parameters in test professionals and control groups. The effect of the lead levels on heamatological parameters is shown on (table. 3). The results showed significant $(\mathrm{p}<0.05)$ decrease in heamatological parameters and WBCs between control and test groups. However the results showed no significant ( $\mathrm{p}<$ 0.05) difference in within groups (f-test) (fig. 3). 


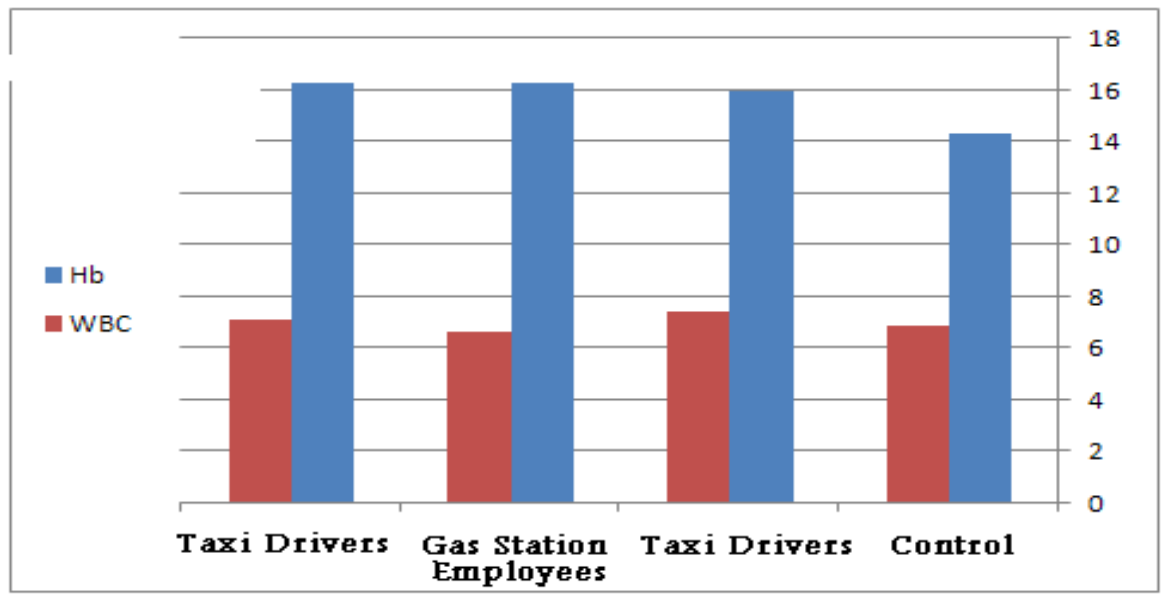

Fig. 3: The Relation between Hematological Parameters, Control and Test Professional Groups

\subsection{Effect of lead level on biochemical parameters}

Table 4: Mean Values of Biochemical Parameters in Control and Test Professional, Experiments within Different Groups

\begin{tabular}{lcccc}
\hline Test groups & $\begin{array}{c}\text { Bus drivers } \\
\text { (Group A) }\end{array}$ & $\begin{array}{c}\text { Gas Station employees } \\
\text { (Group B) }\end{array}$ & $\begin{array}{c}\text { Taxi drivers } \\
\text { (Group C) }\end{array}$ & $\begin{array}{c}\text { Control } \\
(\text { Group D) }\end{array}$ \\
\hline Urea (mmol/L) & $7.11 \pm 0.5745^{*}$ & $8.12 \pm 0.7099^{*}$ & $7.22 \pm 0.5541^{*}$ & $6.58 \pm 0.4604 *$ \\
Creatinine (mg/dL) & $80.6 \pm 4.827 * *$ & $83.8 \pm 4.658^{* *}$ & $84.7 \pm 4.237 *$ & $104.6 \pm 4.219 * *$ \\
$\begin{array}{l}\text { ALT (SGOT) } \\
\text { (U/L) }\end{array}$ & $27.8 \pm 0.7416$ & $37.22 \pm 0.5718^{*}$ & $36.2 \pm 3.834 *$ & $27.62 \pm 0.6611 *$ \\
$\begin{array}{l}\text { AST (SGPT) } \\
(\mathrm{U} / \mathrm{L})\end{array}$ & $35.56 \pm 0.4669^{*}$ & $45.86 \pm 0.8295^{*}$ & $37.6 \pm 2.702 *$ & $28.4 \pm 1.517 *$ \\
\hline
\end{tabular}

* Significant $(\mathrm{P}<0.05)$ increase within the groups (normal and test values t-test)

** Significant $(\mathrm{P}<0.05)$ decrease within the groups (normal and test values t-test)

* Significant $(\mathrm{P}<0.05)$ between groups (ANOVA)

Table. 4. The mean values of the biochemical parmeters in the control and test professional groups. The results showed that, there was a significant increase $(\mathrm{p}<0.05)$ for the values of urea, ALT, AST and test professional groups against control. However, there was a significant decrease $(\mathrm{p}<0.05)$ was observed in creatinine, while there was no significant $(\mathrm{p}<0.05)$ in (group A) for creatinine values (Fig. 4).

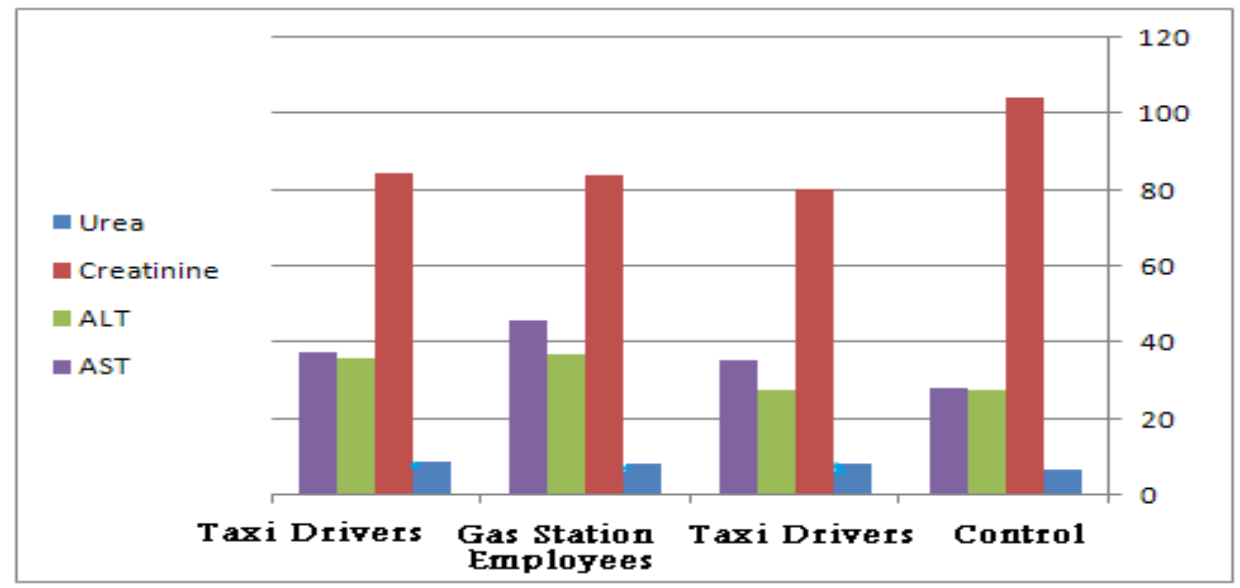

Fig. 4: Biochemical Parameters in Control and Test Professional Groups.

\section{Discussion}

Benzene has been measured in the environment and is commonly emitted in several industrial and transportation settings. As a component of petroleum products, including gasoline and as a trace impurity in industrial products, it results in continued occupational exposure, especially in small, uncontrolled workshops in developing countries [19]. 
Regarding self-reported symptoms associated with leaded gasoline exposure, results showed that the most common selfreported symptoms among gasoline station workers were neurological symptoms, including headache, fatigue, irritability, concentration difficulties, and sleep disturbance. These findings require urgent prevention, intervention, and protection from the ministry of health and other non-governmental organizations. Similar data were reported in many countries, including the neighboring ones [20-22]. According to the present data, there was a significant increase in the prevalence of self-reported symptoms with increasing years of work in the gasoline station. This positive relationship means that increasing work duration led to increase workers exposure to leaded gasoline and put their health at higher risk. Lead toxicity was more frequently encountered with longer-term occupational lead exposure. [23, 24]. Blood lead levels were so high in each of the three exposed groups (A, B and C) compared with control, $(\mathrm{p}<0.05)$, (f-test), where, there was significance increase $(\mathrm{p}<0.05)$ between groups (ANOVA), this agrees with, (Gottesfeld P, Pokhrel AK) [25]. The data showed that, there was significant decrease $(\mathrm{p}<0.05)$ of hemoglobin concentratin and white blood cell's count in all test groups against control (table 3). This agrees with Abousalem, who shows that distinct reductions have been recorded for RBCs, $\mathrm{Hb}$ and $\mathrm{PCV}$ in animals located at the benzene station. This picture of anemia was more pronounced in animals, which were exposed to benzene for longer periods. These hematological disorders may be due to the effect of benzene on the function of bone marrow [26]. Further suggests that prolonged expousure to lead may cause anaemia [27]. While it has significant $(p>0.05)$ between groups (ANOVA). In our study, there was a significant decrease ( $<<$ $0.05)$ was observed in the level of creatinine within all test groups (f-test), and a significant increase $(p<0.05)$ was observed in the level of urea within all test groups (f-test), this agrees with Abousalem. [26], who shows a revealed disturbed kidney function, and this change was manifested by higher levels of urea and creatinine in serum of exposed animals, this can be attributed to, that kidney is an organ of excretion through which most toxic principles are passed out, concerning the effect of air pollutants at benzene on the organ functions (table 4). Due to our data, there was highly significant increase in AST, ALT, in all test groups ( $\mathrm{p}<0.05)$, despite of ALT level in (group A) which was not significant ( $p>0.05$ ) (f-test), (table 4) [26, 28]. This picture is indicative for the impairment of the liver function. These enzymes are involved in the catabolism of amino acids. The measurement of serum levels of these two enzymes are a standard feature of clinical chemistry investigation in regulatory toxicity studies. An increase in these enzymes activities are accepted as an indicator of hepatic toxicity. While $(p<0.05)$ is 0.0001 consider extremely significant between all groups (ANOVA)

\section{Conclusion}

The exposure to Gasoline caused some toxic lesions on some hematological and biochemistry parameters, on professionals. It is also observed that enzyme activity (AST, ALT) increase significantly compared with control. Therefore, exposure to gasoline can cause toxic effect to all professionals.

\section{References}

[1] G. D. Thurston, A critical review of PM10-mortality time-series studies. J. Expo. Anal. Environ. Epidemiol (1996) 6:3-21.

[2] C. A. Goldsmith, L. Kobzik, Particulate air pollution and asthma: a review of epidemiological and biological studies. Rev. Environ. Health (1999)14:121-134. http://dx.doi.org/10.1515/REVEH.1999.14.3.121.

[3] D. Werner, R. Arno, S. Andrea, R. Klaus, Automotive Fuels. In Ullmann's Encyclopedia of Industrial Chemistry. Wiley-VCH, Weinheim (2007).

[4] L. Patrick, Lead toxicity, a review of the literature. Part 1: Exposure, evaluation, and treatment. Altern Med Rev. 11:2-22. Reyes, J. W., 2009. The Impact of Childhood Lead Exposure on Crime. National Bureau of Economic Research (2006).

[5] S.T. Bagley, Characterization of Fuel and After-Treatment Device Effects on Diesel Emissions. Health Effects Institute Report (1996) No. 76.

[6] S. H. Cadle, P. A. Mulawa, E. C. Hunsanger, K. Nelson, R. A. Ragazzi, R. Barrett, G. L. Gallagher, D. R. Lawson, K. T. Knapp, R. Snow, Composition of light-duty motor vehicle exhausts particulate matter in the Denver, Colorado area. Environ. Sci. Technol (1999) 33:23282339. http://dx.doi.org/10.1021/es9810843.

[7] N. D. Kim, Ris M. D., Paul A. S., Omer G. B., Robert L. B., Early exposure to lead and juvenile delinquency. Neurotoxicology and Teratology (2001) 23: (6), 511-518. http://dx.doi.org/10.1016/S0892-0362(01)00184-2.

[8] B. P. Lanphear, R. Hornung, J Khoury., K. Yolton, P. Baghurst, D. C. Bellinger, R. L. Canfield, K. N. Dietrich, R., T. Bornschein, G., S. J. Rothenberg, H. L. Needleman, L. Schnaas, G. Wasserman, J. Graziano, R. Roberts, Low-Level Environmental Lead Exposure and Children's Intellectual Function: An International Pooled Analysis. Environmental Health Perspectives (2005)113 (7): 894-899. http://dx.doi.org/10.1289/ehp.7688.

[9] D. Matthews, Lead abatement, alcohol taxes and 10 other ways to reduce the crime rate without annoying the NRA. Washington Post (2013).

[10] D. Marrs, Ban on lead may yet give us respite from crime. Business Day. M. T.,Mansouri, O.,Cauli, 2009. Motor alterations induced by chronic lead exposure. Environmental Toxicology and Pharmacology (2013) 27:307-13.

[11] R. Wolpaw, Jessica, Environmental policy as social policy? The impact of childhood leads exposure on crime. National Bureau of Economic Research. (2013).

[12] H. L. Abdel Monem, I. A. Adnan, H. Abed Al-Rahman,, M. Y. Maged, Exposure of gasoline station workers to leaded gasoline in the Gaza Strip: Awareness and self-reported symptoms. Annals of Alquds Medicine. Issue (6): (2010).

[13] F. Bernard, G. Ph. Jose, C. Nemi, Schalm's veterinary Hematology 5th edlippino citt Williams and Wilkins co. Philadephia, Baltimor. New York, London, Hong Kong, Tokyo: (2000).

[14] L. I. Simeonove, D. Maria, F. Antonio, Environmental heavy metal pollution and effect on child mental development: Risk Assessment and prevention strategies. Springer Science Business Media (2011). http://dx.doi.org/10.1007/978-94-007-0253-0.

[15] D. Peter, M. D. Bryson, Comprehensive Review in Toxicology for Emergency Clinical. Third Edition (1996) P: 605.

[16] S. Reitman, S. Frankel, A colorimetric determination of serum glutamic oxaloacetic and glutamic pyruvic transaminase. Am. J. Clin. Path (1957)28: 56. 
[17] H. Bartels, M. Böhmer, C. Heierli, Serum creatinine determination without protein precipitation. Clin Chim Acta (1972) 37:193-97. http://dx.doi.org/10.1016/0009-8981(72)90432-9.

[18] G. W. Snedecore, W. G. Cochran, Statistical methods. 6th Erd., Lowa stateuniv. Press Ames, Lowa USA (1980).

[19] C. P. Weasel, Benzene exposure: an overview of monitoring methods and their findings. Chem Biol Interact (2010) $184: 58-66$. http://dx.doi.org/10.1016/j.cbi.2009.12.030.

[20] K. A. Essa, Lead, the ugly trace element: occurrence, effects, screening and treatment. Eastern Mediterranean Health Journal (1999) 5:798802.

[21] A. A. Bener, Pilot survey of blood lead levels in various types of workers in the United Arab Emirates. Environment International (2001) 27:311-14. http://dx.doi.org/10.1016/S0160-4120(01)00061-7.

[22] G. Cunningham, Lead-toxicology and assessment in general practice. Australian Family Physician (2007) 36:1011-13.

[23] I. Nuwayhid, K. McPhaul, R. Bu-Khuzam, Determinants of elevated blood lead levels among working men in Greater Beirut. Lebanese Medical Journal (2001) 49:132-9.

[24] S. Stoleski, K. Jovanka, S. Elisaveta, R. Sne`zana, M. Dragan, M Jordan., Adverse effects in workers exposed to inorganic lead. Arh Hig Rada Toksikol. (2008) 59:19-29. http://dx.doi.org/10.2478/10004-1254-59-2008-1866.

[25] P. Gottesfeld, A. K. Pokhrel, Lead exposure in battery manufacturing and recycling in developing countries and among children in nearby communities. J Occup Environ Hyg. (2011) 8:520-32. http://dx.doi.org/10.1080/15459624.2011.601710.

[26] M. Abousalem, A. Elgerwi, A. El-Mashad, Biotoxic and Haemotoxic Effects of Air Pollutants at Benzene Station on Albino Rats. International Journal of Animal and Veterinary Advances. (2012) 4(3): 187-190.

[27] M. W. Shannon, S. W. Borron, M. J. Burns, W. Haddad, Clinical Management of Poisoning and Drug Overdose. 4th Edition, Saunders Elsevier, Westline: (2007).

[28] R. M. Ivana, P. Emilija, Lead -Apreanalytical/ analytical variable in clinical Chemistry. Physics, Chemistry and Technology (2014) Vol. 12, No $1,73-86$. 